\section{Associated callus culture technique for in vitro growth of rust fungi}

\author{
Aniket A. Kuvalekar ${ }^{1}$ \& Kanchanganga R. \\ Gandhe $^{2}$
}

1,2 PG Research Centre, Department of Botany, Modern College of Arts, Science and Commerce, Shivajinagar, Pune, Maharashtra 411005, India

Email: ${ }^{1}$ kuaniket@gmail.com

Abstract: Uromyces hobsoni, a rust fungus, infects Jasminum officinale var. grandiflorum. The infection frequently leads to malformations in tissues, mainly leaves and stems. Disease progression can be assessed morphologically by observing the extent of malformation and occurrence of sporulation. The rust fungi, in general, are obligate parasites, and need a living host to complete their life cycle. The difficulty of in vitro propagation of rust fungi has been a major obstacle in their detailed biochemica and molecular analysis. In this paper, we report successful in vitro culture of rust fungi with induction of callus from infected leaves of host plants which contain initial differentiated structures like haustoria and intercellular hyphae. This 'associated callus culture' technique has opened new paths for studying hostpathogen interactions of rust fungi.

Keywords: Associated callus culture, haustoria, hypertrophy, host-pathogen, interaction, malformations.

Rust fungi are obligate parasites which require a living host for growth, reproduction and completion of their life cycle (Eckardt 2006). There have been a few reports of in vitro culturing of rust fungi but these studies could not be repeated by other workers (Scott \& Maclean 1969; Bose \& Shaw 1974; Wiethölter et al. 2003). The inability to culture

Date of publication (online): 26 August 2010

Date of publication (print): 26 August 2010

ISSN 0974-7907 (online) | 0974-7893 (print)

Editor: V.B. Hosagoudar

\section{Manuscript details:}

Ms \# 02263

Received 16 July 2009

Final revised received 11 August 2010

Finally accepted 12 August 2010

Citation: Kuvalekar, A.A. \& K.R. Gandhe (2010). Associated callus culture technique for in vitro growth of rust fungi. Journal of Threatened Taxa 2(9): 1140-1143

Copyright: () Aniket A. Kuvalekar \& Kanchanganga R. Gandhe 2010 Creative Commons Attribution 3.0 Unported License. JoTT allows unrestricted use of this article in any medium for non-profit purposes, reproduction and distribution by providing adequate credit to the authors and the source of publication.

Acknowledgements: The authors are thankful to University Grants Commission, New Delhi for providing financial assistance and to the authorities of Modern College, Pune for providing infrastructure facilities.

\section{OPEN ACCESS | FREE DOWNLOAD (C) (i) @ि}

rust fungi in defined conditions has been a major impediment to studying host-pathogen interactions and performing detailed biochemical and molecular analysis. The present study was undertaken to investigate the competence of rust fungus Uromyces hobsoni Vize to grow with host tissues in artificial culture media.

\section{Material and methods}

Collection of plant material and tissue explant preparation: The leaves of Jasminum officinale var. grandiflorum (L.) Bailey, both healthy and heavily infected by rust fungus Uromyces hobsoni Vize. (Image 1 a-d) were chosen for culture experiments. The leaves were collected from the same host plant in the field and preserved in brown paper bags (storage in polythene bags leads to development of moisture and hyperparasites on the tissues). Leaves were deemed infected if they contained telial pustules. Explants were washed thoroughly under running tap water to remove dust and other debris, further washed with an aqueous suspension of $0.01 \%(\mathrm{v} / \mathrm{v})$ Tween 20 (a liquid detergent) for 10 minutes followed by aqueous suspension in Dettol disinfectant for 10 minutes. Further processing of explants was carried out under aseptic conditions in a horizontal laminar air flow cabinet. The explants were washed with sterile distilled water, treated with $70 \%$ alcohol for 30 seconds, surface sterilized with an aqueous solution of $0.1 \%$ mercuric chloride for two minutes and inoculated with fungus in test tubes containing sterile Murashige and Skoog's growth medium (Murashige \& Skoog 1962) supplemented with 2 $\mathrm{mg} / \mathrm{L} 2,4-\mathrm{D}$ with $3 \%$ sucrose $(\mathrm{w} / \mathrm{v})$ and $0.8 \%$ agar $(\mathrm{w} / \mathrm{v})$ at $\mathrm{pH}$ 5.5-5.7.

Incubation and Measurement: Cultures were incubated at $27 \pm 2{ }^{\circ} \mathrm{C}$ at 1200 lux fluorescent white light at 16 hours photoperiod. Cultured explants were observed regularly for contamination and callus development. Growth of callus tissue was analyzed at an interval of four days after the initiation of culture. Ten cultures from each experiment were used to determine the fresh weight of callus, which was then dried in a hot air oven at $40^{\circ} \mathrm{C}$ until a constant dry weight was obtained. Microscopic observation of calli involved looking for fungal structures including mycelia and haustoria via cotton blue mounting. Final development was assessed on the $32^{\text {nd }}$ day post inoculation for 10 callus cultures each from healthy and infected tissues. Each experiment was done in triplicate and the number of cultured explants per replicate was 25.

\section{Results and Discussion}

The study of disease development by rust fungi is difficult due to inaccessibility to pure cultures. Rust fungi are obligate parasites which require the presence of a 

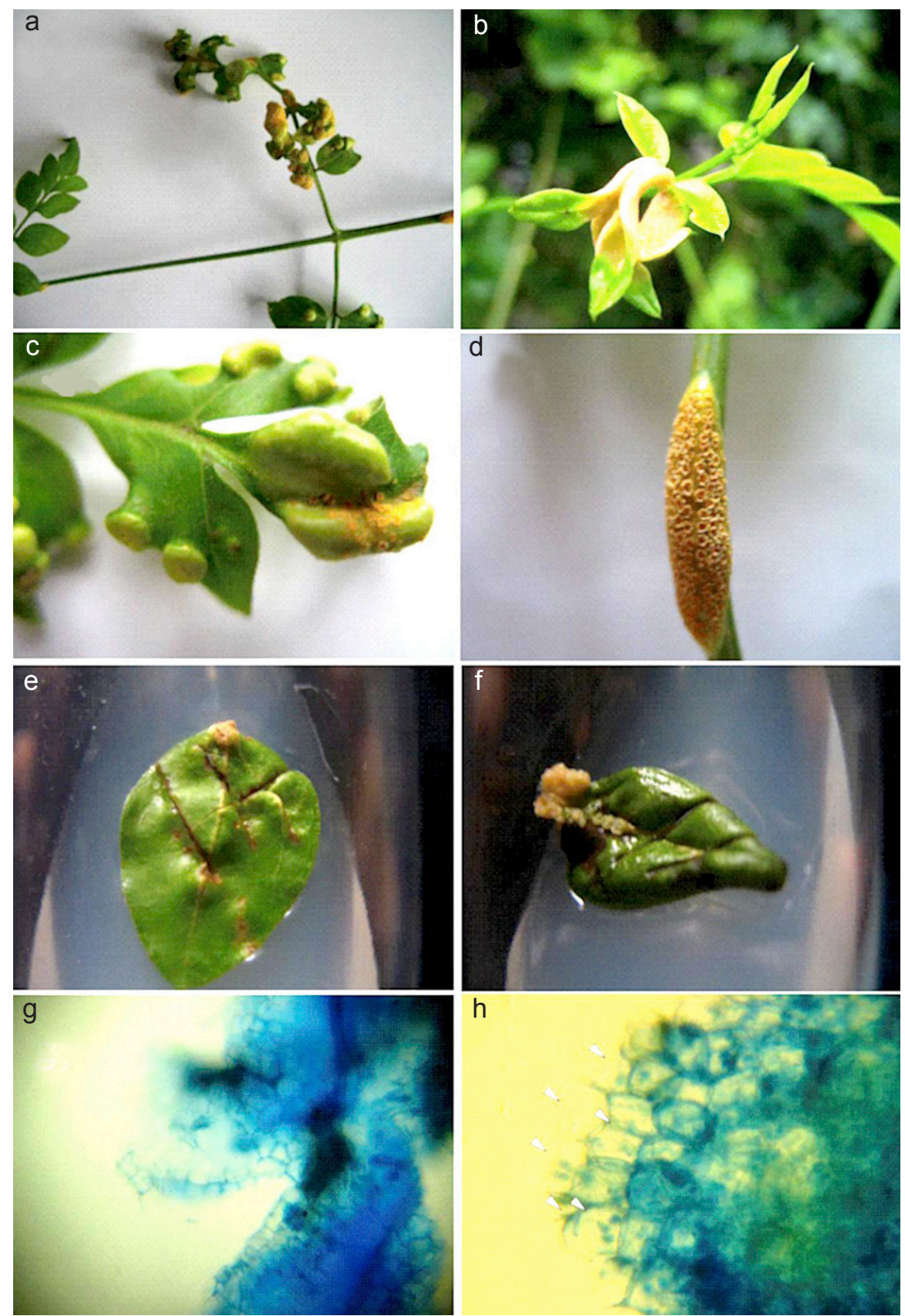

Image 1. Malformations induced in the host due to the infection of $U$. hobsoni (a-d); Callus induction from uninfected (e) and infected (f) leaves of $J$. officinale var. grandiflorum; Photomicrograph of the callus derived from uninfected (g) and infected (h) leaves. Note the haustoria and intercellular hyphae clearly distinguishable in the callus derived from the infected leaves (arrows) (๑ Aniket A. Kuvalekar) living host for their growth, reproduction and completion of their life cycle (Savile 1976). There are limited studies of the in vitro cultures of rust fungi, most of which could not be repeated by other workers (Scott \& Maclean 1969; Bose \& Shaw 1974; Wiethölter et al. 2003). Hotson \& Cutter (1951) for the first time reported successful axenic culture of Gymnosporangium juniperi - virginianae. They also showed that saprophytic cultures of the rust can reinfect the host to produce characteristic fruiting bodies. Staples et al. (1983) and Allen et al. (1991) have reported that uredospores of various rust fungi can be germinated on artificial membrane grooves. Hu \& Amerson (1991) reported single geneotype axenic cultures of Cronartium quercuum f. sp. fusiformae which can be repeatedly cultured axenically from single spores. Successful axenic culture has also been reported for the western gall rust (Endocronartium harknessii) using the galls produced on the host (Allen et al. 1988). Diner \& Mott (1985) reported that the in vitro generated vegetative hyphae from the basidiospores of Cronartium ribicola could infect the in vitro grown propagules of western white pine and showed intracellular haustoria. Anikster (1986) showed the germination of teliospores from different rusts which could even occur in water agar. Recent studies with in vitro cultures of rust fungi have revealed that the growth and differentiation of the structures like haustorial mother cells 
Table 1. Fresh weight and dry weight of the calli initiated from the healthy and infected explants. The calli from the infected explants grew faster but seized the growth after $32^{\text {nd }}$ day post callus initiation. The calli from the healthy tissues grew slowly but continued the growth beyond the reported time frame. At each reported time period, the calli from eight different explants of each sample were used to determine the growth

\begin{tabular}{|c|c|c|c|c|}
\hline \multirow{2}{*}{$\begin{array}{c}\text { Days post callus } \\
\text { initiation }\end{array}$} & \multicolumn{2}{|c|}{ Callus from healthy explants } & \multicolumn{2}{c|}{ Callus from infected explants } \\
\cline { 2 - 5 } & Fresh Weight (g) & Dry Weight (g) & Fresh Weight (g) & Dry Weight (g) \\
\hline 4 & 0.005 & 0.001 & 0.004 & 0.001 \\
\hline 8 & 0.008 & 0.003 & 0.009 & 0.005 \\
\hline 12 & 0.011 & 0.005 & 0.014 & 0.014 \\
\hline 16 & 0.014 & 0.010 & 0.019 & 0.024 \\
\hline 20 & 0.018 & 0.012 & 0.026 & 0.029 \\
\hline 24 & 0.022 & 0.018 & 0.032 & 0.030 \\
\hline 28 & 0.026 & 0.023 & 0.035 & 0.031 \\
\hline 32 & 0.028 & 0.024 & 0.035 & \\
\hline
\end{tabular}

is dependent upon the synergistic action of chemical and physical signals (Wiethölter et al. 2003). Pure cultures of the rust fungi are also reported from the basidiospores and aeciospores (Diner 1999; Moricca et al. 2000). Pei \& Gibbs (1992) have reported the continuously growing rust cultures of Peridermium pini where aeciospores were used as the starting material. Thus there are very few reports of successful rust cultures.

Maheshwari et al. (1967) have earlier reported the successful growth of rust fungus on the callus tissue of the host. They reported that upon inoculation of rustinfected sunflower cotyledons and red cedar galls induced by cedar-apple rust on artificial media, the host tissue proliferated but the rust mycelium did not invade the newly formed tissues. They also reported that the growth of callus tissue, when kept in contact with uredospores germinated on collodion membranes, also failed.

The main reason for failure of the continuous growth of the rust fungus in vitro or in association of the host might be their requirement of specific signals which are tightly linked to development of the host plant (Staples 2000). The callus tissue itself is an unorganized mass of cells and the rust fungus invading the cells and/or callus may not get the required developmental signals from the host for the profuse growth and sporulation.

Hence the report in the present study is particularly significant as the growth of the fungal mycelia is observed in the callus with the formation of specialized feeding structures. In the present studies, cultures of healthy and infected leaves showed initiation of callus in 8-10 days (Image 1 e-f). The calli grew quite slowly and formed a mass at the site of induction. After 32 days of callus initiation, growth of callus originating from infected leaves seized and it turned brown, whereas calli from healthy leaves continued to grow.

Microscopic examination of calli from healthy and infected leaves showed the presence of irregular cell masses. Cells from calli induced from infected leaves showed presence of haustoria and also inter and intracellular hyphae. These structures were clearly visible in callus initiated from the infected leaves. The callus from infected leaves grew faster (Table 1) and the cells appeared larger in diameter compared to those in the callus from healthy leaves (Image $1 \mathrm{~g}$-h).

In the present study, the growth of rust was reported along with the callus in the infected tissues of $\mathrm{J}$. officinale var. grandiflorum. The intercellular hyphae and haustoria were clearly distinguishable in the callus cultures derived from the infected tissues.

Although axenic cultures have been established for many rusts they remain slow-growing and the essential nature of their in vitro growth requirements remains unknown. There may not be a special requirement for nutrients but rust development may be tightly linked to signals from the host plant (Staples 2000).

In the present study, the medium used for the culturing was a plant tissue culture medium designed to aid the growth of plant tissues. The high concentration of auxin in the medium leads to development of callus. The fungal hyphae already present in the infected host tissues grow and invade the freshly developed callus. The fungal cells may get more nutrients from such cells which are profusely growing but the lack of developmental signals from the host tissue may lead to termination of the fungal growth. The present technique of 'associated callus culture' can be used for indefinite growth of the rust fungi in vitro with the host allowing for availability of the tissues grown under controlled conditions with the rust fungi. The technique has opened the way to such type of study in a wide variety of host-rust systems. This technique may provide the easier way for the in vitro culture of rust fungi and study of host-parasite interaction.

With the help of this technique, the biochemical signals which govern the growth of rust in the living host cells needs to be addressed. Further it can be checked if the preconditioned fungal tissues are able to grow on the 
defined media. The studies to address these questions are in progress.

\section{REFERENCES}

Allen, E.A., B.E. Hazen, H.C. Hoch, Y. Kwon, G.M.E. Leinhos, R.C. Staples, M.A. Stumpf \& B.T. Terhune (1991). Appressorium formation in response to topographical signals by 27 rust species. Phytopathology 81: 323-331.

Allen, E.A., P.V. Blenis \& Y. Hiratsuka (1988). Axenic culture of Endocronartium harknessii. Mycologia 80(1): 120-123.

Anikster, Y. (1986). Teliospore germination in some rust fungi. Phytopathology 76: 1026-1030.

Bose, A. \& M. Shaw (1974). Growth of rust fungi of wheat and flax on chemically-defined media. Nature 251: 646-648.

Diner, A.M. \& R.L. Mott (1985). In vitro inoculation of western white pine tissue culture propagules with vegetative hyphae of Cronartium ribicola. Phytopathology 75(10): 1130-1131.

Diner, A.M. (1999). Direct mechanical dispersion and in vitro culture of fusiform rust fungus single basidiospores. Mycologia 91(6): 1102-1103.

Eckardt, N.A. (2006). Identification of rust fungi avirulence elicitors. Plant Cell 18: 1-3.

Hotson, H.H. \& V.M. Cutter (1951). The isolation and culture of Gymnosporangium juniperi- virgininae schw. upon artificial media. Proceeidngs of National Academy of Sciences USA 37: 400-403.

Hu, A. \& H.V. Amerson (1991). Single genotype axenic cultures of Cronartium quercuum f. sp. fusiforme. Phytopathology 81 : 1294-1297.
Maheshwari, R., A.C. Hilderbrandt \& P.J. Allen (1967). Factors affecting the growth of rust fungi on host tissue cultures. Botanical Gazette 128(3-4): 153-159.

Moricca, S., A. Ragazzi \& B.N. Longo (2000). In vitro growth of the aspen rust Melampsora larici-tremulae. Mycological Research 104: 1250-1257.

Murashige, T. \& F. Skoog (1962). A revised medium for rapid growth and bio-assays with tobacco tissue cultures. Physiologia Plantarum 15: 473-497.

Pei, M.H. \& J.N. Gibbs (1992). Axenic culture of Peridermium pini from single aeciospores. Plant Pathology 41(1): 91-94.

Savile, D.B.O. (1976). Evolution of the rust fungi (Uredinales) as reflected by their ecological problems. Evolutionary Biology 9: 137-207.

Scott, K.J., \& D.J. Maclean (1969). Culturing of rust fungi. Annual Review of Phytopathology 7: 123-146.

Staples, R.C. (2000). Research on the rust fungi during the twentieth century. Annual Review of Phytopathology 38: 4969.

Staples, R.C., H. Grambow, H.C. Hoch \& W.K. Wynn (1983). Contact with membrane grooves induces wheat stem rust uredospore germlings to differentiate appressoria but not vesicles. Phytopathology 73: 1436-1439.

Wiethölter, N., S. Horn, K. Reisige, U. Beike \& B.M. Moerschbacher (2003). In vitro differentiation of haustorial mother cells of the wheat stem rust fungus, Puccinia graminis f. $\mathrm{sp}$. tritici, triggered by the synergistic action of chemical and physical signals. Fungal Genetics and Biology 3(3): 320326. 